\title{
Danskere i Prag omkring år 1600
}

Af Herman Kølln, tidl. dansk lektor i Prag

\section{Tyge Brahes fodspor}

Af kongerne i den bøhmiske kongerække er der særlig grund til at nævne to: den første, Premysl Otakar I (1197-1230), fordi han var dronning Dagmars far, og den største, Karl IV (1346-78), der nok mest var tysk-romersk kejser, men alligevel styrede sit stamland med al mulig landsfaderlig omsorg og gjorde Prag til residensstad og storby. Prag, der indtil da havde bestået af tre byer, Borgbyen, Lillesiden og Den gamle By, udvidede han betydeligt ved at grundlægge Den ny By. Han var ivrig efter også at gøre Prag til et åndeligt centrum, var bygmester for Skt. Vitus-katedralen og en del kirker og klostre og fik i 1344 paven til at oprette ærkebispesæde her. 1348 oprettede han Karlsuniversitetet, der som det første universitet i Mellem- og Nordeuropa også blev besøgt af mange skandinaviske studenter.

Af Habsburgerne, der var østrig-ungarske kejsere og tillige bøhmiske konger i den lange tid fra 1526 til 1918, kan man fremhæve Rudolf II (1576-1611), der igen gjorde Prag til residensstad. Han havde ikke megen statsmandskløgt, i politik måtte han støtte sig til horoskoper, og det gik også meget godt. Ham er der sikkert under de sidste årtiers ensretningsproces i Tjekkoslovakiet sendt mange venlige tanker til, for han var meget forstående over for andre nationaliteter, trosretninger og verdensopfattelser. Han førte ingen store krige, men optrådte i vid udstrækning som mæcen, samlede store kunstskatte og omgav sig med store skarer af kunstnere og videnskabsmænd fra ind- og udland.

Tyge Brahe var en af disse intellektuelle. Hans ophold i Prag var dog langtfra en lykkelig afslutning på et liv. Han måtte til stadighed udarbejde nye horoskoper til kejseren, der blev ikke megen tid til videnskabeligt arbejde, og allerede ved ankomsten var han mærket af en fremskreden prostata-hypertrofi. Efter en fest den 13. oktober 1601 hos den mægtige adelsmand Peter Vok af Rosenberg kunne 
han ikke længere komme af med vandet. Han døde af urinforgiftning den 24 . oktober.

Man kan nok undre sig over den ærefrygt, tjekkerne nærer over for vores landsmand. Man kan da en gang imellem få indtryk af, at man hernede gør mere ud af ham, end vi gør i Danmark. Han anses altid som den førende skikkelse blandt de intellektuelle, der omgav kejseren. Som kejserlig consiliarius indtog han ganske vist også en meget høj stilling, men opholdet i Prag var så kort, det varede kun godt et år. I ærefrygten for Brahe blander der sig nok en del stolthed. Tjekkerne er stolte over, at der dog engang - for længe siden - var en tid, da menneskerettighederne ikke rangerede allerdybest nede, og man endda kunne tilbyde asyl til udenlandske intellektuelle, der på grund af religiøs overbevisning eller for andre årsagers skyld måtte forlade deres fædreland. De er stolte over, at Brahe kunne tilbringe sin sidste tid i Prag, og at han her kunne videregive stafetten til en anden udlænding, Johannes Kepler. Vigtigt er det nok også, at Prag huser en del Brahe-minder, først og fremmest naturligvis graven.

Brahe blev begravet i Tejn-Kirken på Storetorv (Velky rynek, nu Staromestské námestí) i Den gamle By. Det var Prags centrum og det vigtigste af alle de mange torve - Kultorvet, Frugttorvet, Hestetorvet, Kvægtorvet o.s.v. - helt til midten af det 19. århundrede, da Hestetorvet under navn af Wenzelspladsen (Václavské námestí) overtog føringen.

H.C. Andersen skriver i En Digters Bazar (1842) om Brahes grav: "Højt paa Bjerget med Udsigt over Stad, Flod og skovbegroede Øer ligger det gamle Hradschin, Kirken her gjemmer i en prægtig Sølvkiste St. Nepomuks Liig; hvilken Pragt herinde, hvilken Naturpragt ude, og dog er dette ikke det sted i Prag, den Danske først besøger; nede ved Torvet ligger en lille, fattig Kirke, en Buegang og en snever Gaard fører derind ... Hvis Been smuldre derinde? En Landsmands! ..."

Tejn-kirken er her blevet til en lille, fattig kirke. Det svarer ikke helt til det indtryk, almindelige dødelige har af kirken. Jeg tillader mig at citere en artikel, som Det kongelige Biblioteks egen Brahe-ekspert Harald Mortensen (1878-1957; om ham, se Fund og Forskning 1959, s. 7-11) under krigen skrev til det svenske tidsskrift Cassiopeia: "Kirken med de to 81 Meter høje Taarne er en af de pragtfuldeste Kirkebygninger i Europa, men H.C. Andersen har af den snevre Adgang til og den lille mørke Gaard foran Kirken fået et forkert Indtryk af denne. Teynkirken skal ses ude fra Torvet; der får man indtryk af dens Mægtighed."

H.C. Andersen antyder svagt, at Tyge Brahe som en anden helgen burde have ligget oppe ved slottet i Skt. Vitus-katedralen. Det kan der være noget rigtigt i. 


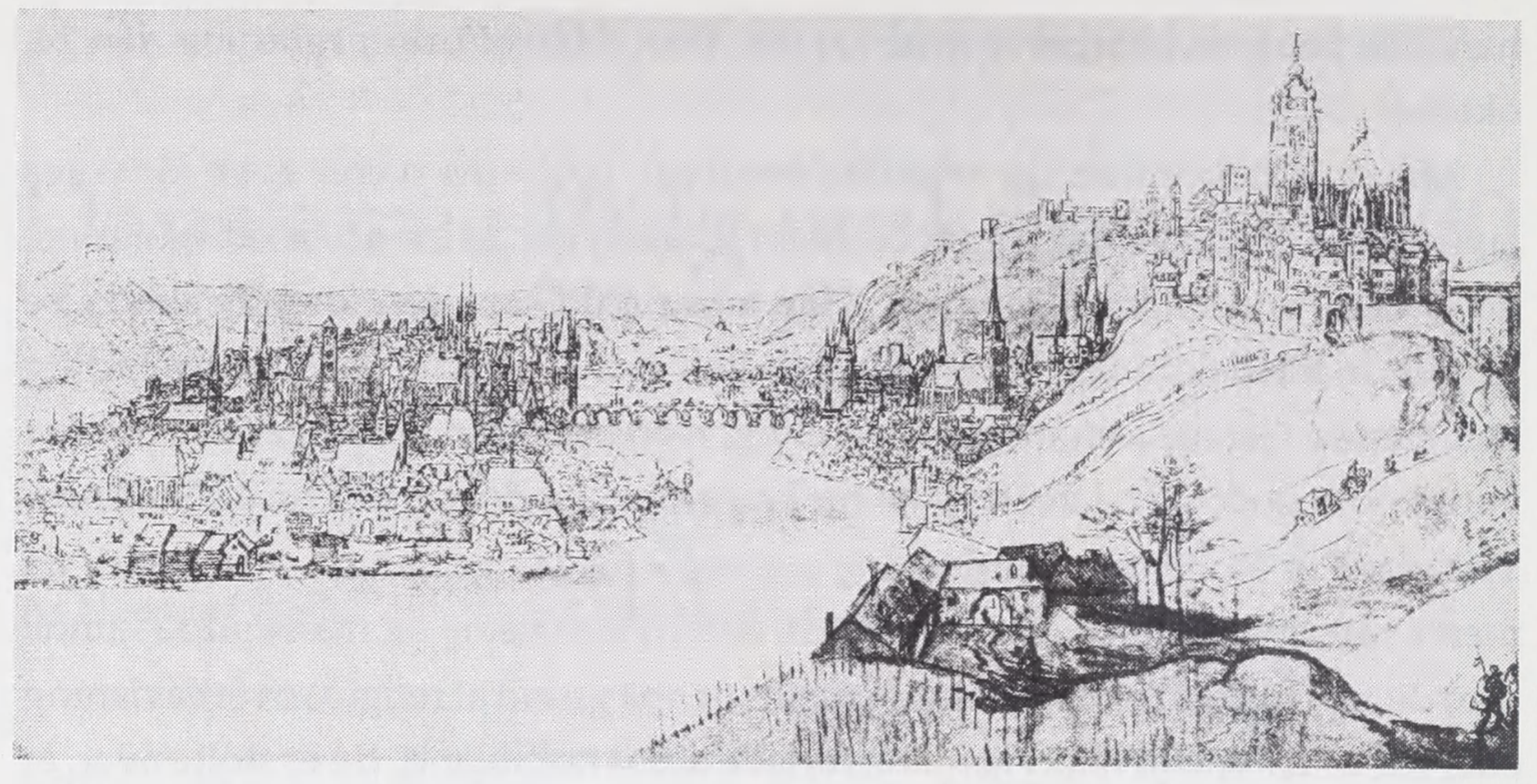

Prag omkring år 1600. Tegning af Roelant Savery.

Katedralen var ganske vist dengang ikke helt så imponerende, som den er nu, kirkerummet er siden i retning mod vest blevet udvidet til dobbelt længde. Men Brahe hørte Borgbyen til. Heroppe boede han, her måtte han være for hånden, når kejseren kaldte, her plejede han omgang med andre adelsmænd, og herfra kunne han også bedst iagttage stjernehimmelen.

Men man må ikke glemme, at Brahe var protestant. Han kunne ikke blive begravet i Borgbyens kirker, de var alle katolske. Han blev begravet i den fornemste af de protestantiske kirker, i Tejn-kirken, der faktisk uden nogensinde at blive kaldt det var katedral, - katedral for det store flertal af befolkningen. Begravelsen foregik under opbud af al mulig pomp og pragt. Kejseren selv var til stede, og ligtalen blev holdt af en god bekendt, Johannes Jessenius, der 159899 i seks måneder i sin professorbolig i Wittenberg havde huset Brahe, indtil han kunne drage videre til Bøhmen.

Graven ligger ved højre korpille. Selve graven er markeret af en stenplade med Brahes navn, og pillen bærer et epitaf og et rødbrunt relief, der i replik også kendes fra bl.a. Det nationalhistoriske Museum på Frederiksborg. Her hænger også et lille dannebrogsflag, så ingen behøver at gå forkert af graven. Flaget bliver fornyet af den danske ambassadør, der fra tid til anden besøger kirken.

Kirkens legendariske betjent gennem mere end et halvt århundrede, Karel Davídek (1897-1975), var en dygtig rundviser. Han var æresmedlem af det ærkebiskoppelige konsistorium og som vogter af Tyge Brahes grav også dekoreret med en af de vist nok meget få danske medaljer, der fandt vej til den anden side af jerntæppet. 
Tidligere kunne man når som helst komme og besøge kirken. Efter Davídeks død er man blevet karrig med åbningstiden, og p.t. kan graven kun beses i forbindelse med (men ikke under) en messe. Denne mangel og samtidig den af Andersen antydede mangel på et værdigt minde oppe i Borgbyen er der dog siden delvis rådet bod på.

I 1971, da ånden fra 1968 endnu levede, blev der afholdt en anonym konkurrence om det bedste forslag til en statue for Brahe og Kepler. Forslagene blev vist frem på en særlig udstilling på rådhuset (over for Tejn-kirken). Blandt dem var der et par dristige, for ikke at sige himmelråbende desperate forslag, der godt kunne lede tanken hen på allehelgenlitaniets "bed for os", som H.C. Andersen hørte i Tejn-kirken: "Det klinger som et huult hendøende Suk fra Afgrunden, det vælder frem som en Smertens Bølge, et Jammerskrig ...". Disse forslag fandt nok nåde for dommerkomiteens øjne, men havde faktisk ingen chancer for at blive realiseret. En sokkel til monumentet blev afsløret samme år. Der hengik så en lang række år, inden spændingen udløstes i 1983, da der pludselig på et nyt og større fundament oppe i et parkanlæg foran Kepler-gymnasiet (over for hotel Savoy og ikke mange skridt fra hotel Pyramida, hvor så mange danskere har boet) stod en statue af de to astronomer, som på overbevisende måde opfyider alle krav til monumentalitet og menneskeskildring. Det var forslaget fra tredjepræmietageren, Josef Vajce, der endelig var blevet realiseret.

Umiddelbart foran Kepler-gymnasiet er en del af plænen indhegnet med et lavt træstakit. Her kan man linde på en låge og gå ind og dvæle ved grundridset af den ejendom, hvor Brahe boede de sidste otte måneder af sit liv. Ruinerne blev udgravet i 1902 og igen i 1931, da gymnasiet blev bygget. Ved indgangen til gymnasiet er der sat en mindeplade op, og inde i bygningen hænger Antonín Lhotáks buste af Tycho Brahe (replik på Københavns Universitets Astronomiske Institut).

Brahe-Kepler-statuen er et naturligt udgangspunkt for en spadseretur ned til slottet. Vi følger dog ikke den lige vej, men drejer af ved Loreto og kapucinerklosteret, hvis munke ifølge sagnet forstyrrede Brahe ved idelig klokkeringning (slg. J.L. Heibergs digt Den nordiske Magus, Urania 1846) og går videre ned ad Kapucinergade til et tidligere gæstgiveri "Ved den gyldne Grif" i Ny Verden (Novy svet, matr. nr.76/IV). Her boede Brahe en kort overgang, da han ijuli 1600 kom til Prag. Dette sted har der ikke stået så meget blæst om, efter at det i 1902 i et stort billedværk om det gamle Prag (V. Jansa, J. Herain Stará Praha) blev hævdet, at Brahe ikke kunne have boet under så små forhold. Men den nuværende toetages bygning måler dog 15 gange $9 \mathrm{~m}$ i grundareal, og Brahe omtaler 


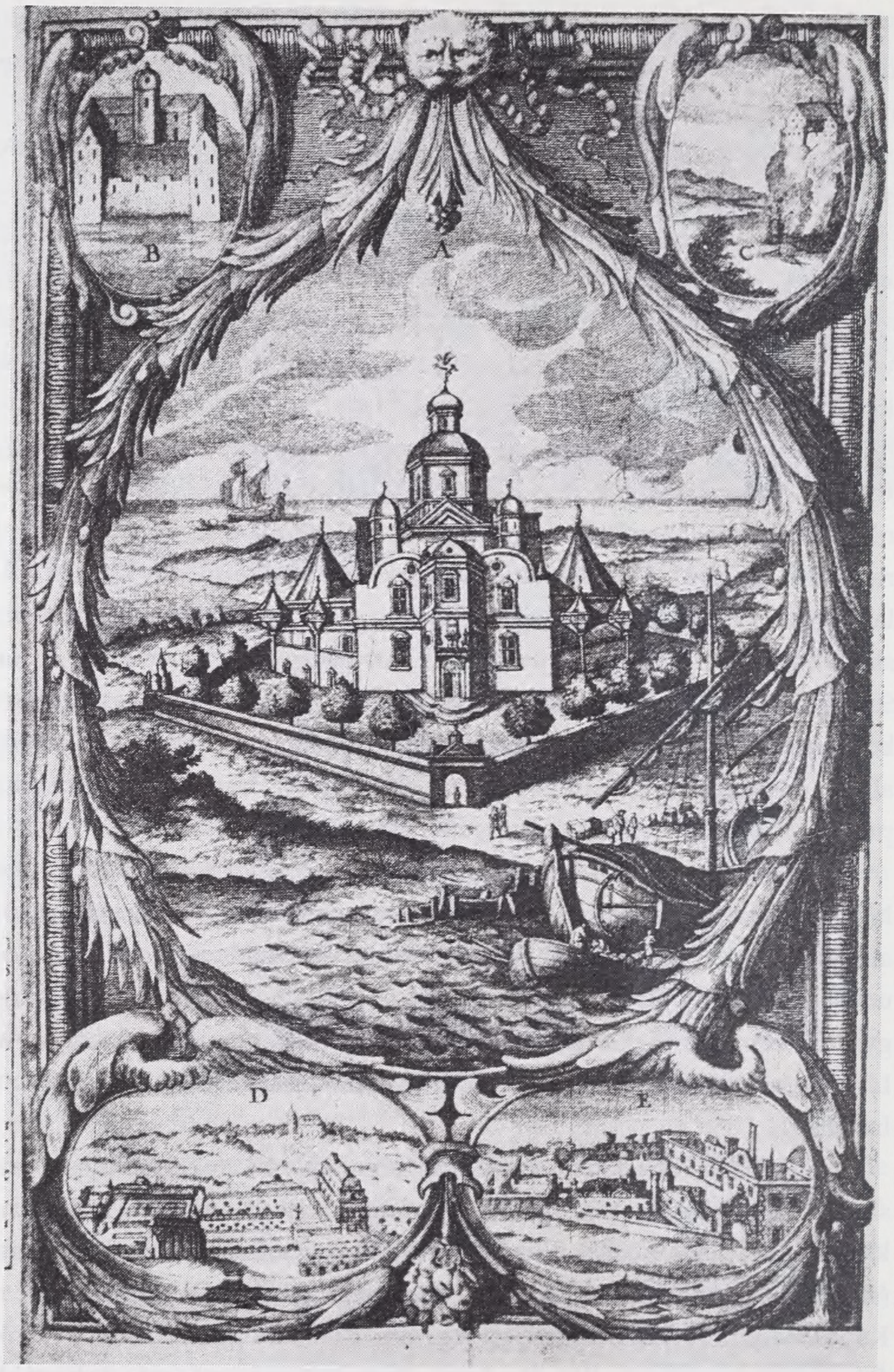

I Historia coelestis jussu S.C.M. Ferd. III. edita, complectens observationes astronomicas varias ad historiam coelestem spectantes, Emmrich, Regensburg 1672, findes dette billede af Uraniborg, med hjørnebilleder af slottet i Wandsbeck, slottet i Benátky nad Jizerou, Bøhmen, af Belvedere iPrag og af vicekansler Jakob Curtius' ejendom i Prag, Brahes sidste bopæl. 
selv stedet i et brev: "apud Insigne aurei Gryphei" (Opera omnia 8, s. 341). En mindeplade ved indgangen, opsat i 1901, har heldigvis fået lov til at blive hængende.

Vi går nu op ad Kannikestræde, forbi Peter Vok af Rosenbergs palæ (senere Schwarzenbergernes palæ, nu tøjhusmuseum), hvor Brahe var til fest hin skæbnesvangre oktoberdag, og ind på slotsområdet. Oppe i et borgtårn lige bag katedralen - Mihulka hedder det - er der en meget overkommelig udstilling, som er viet naturvidenskab og kunsthåndværk ved Rudolf IIs hof. Her indtager Brahe sin plads side om side med Kepler og tidens mange guldmagere.

Fra slottet går man videre gennem Kongens Have til Dronning Annas lystslot, Belvedere, et henrivende renæssanceslot, hvis øvre stokværk Brahe brugte til observatorium. Heroppefra er der noget nær ideelle observationsmuligheder og også en glimrende udsigt ned mod byen. Her blev der i 1971 afholdt en storslået Brahe-Kepler-udstilling.

En del Brahe-minder findes på museer og biblioteker. Med jævne mellemrum viser Bymuseet på en lille særudstilling en del af det tøj, Tyge Brahe havde på ved begravelsen. Det blev fremdraget ved åbning af graven i 1901. Museet fik dengang overladt en baret i gyldent fløjl, et kappeærme i mørkerød brokade, en hvid uldstrømpe og en meget lille sko af brunt fløjl. Skelettets længde blev målt til $170 \mathrm{~cm}$.

Efter Brahes død blev hans instrumenter og bøger spredt for alle vinde. To af hans instrumenter er opstillet i Teknisk Museums righoldige samling af gamle astronomiske instrumenter. Et tredje kan beses i den mindestue for Tyge Brahe, der er indrettet på museet på slottet i Benátky nad Jizerou,ca. 30 km fra Prag, hvor Brahe havde boet et års tid, inden kejseren kaldte ham til Prag.

Ikke så få bøger, i alt et halvt hundrede bind, og enkelte håndskrifter fra Brahes privatbibliotek findes samlet på Nationalbiblioteket i Prag (der i øvrigt også ejer resterne af Henrik Rantzaus privatbibliotek samt et bredt udsnit af skrifter forfattet af den tids danske litterater). Særlig interessant er et eksemplar af Copernicus' Derevolutionibus orbium coelestium med talrige randbemærkninger fra Brahes hånd. Det blev udgivet i faksimile i 1971.

Man kan som dansker nok beklage, at næsten intet af boet efter Brahe kom tilbage til Danmark. Helt forfordelt blev vi nu ikke. Observationsjournalerne fra Hven, hvoraf Kepler udledte de berømte tre keplerske love for planeternes bevægelse omkring solen, blev omkring 1655 af Keplers søn solgt til Frederik III. De tæller naturligvis for mange instrumenter og bøger. De opbevares under lås og slå på Det kongelige Bibliotek i København. 


\section{Bertel Knudsen Aquilonius i Prag 1609-10}

Hvis vi vil have et mere nuanceret billede af forholdene i Bøhmen på Rudolf II's tid, kan vi naturligvis ikke nøjes med at betragte kejseren som mæcen og midtpunkt for en stor skare kunstnere og videnskabsmænd. Vi kan fastholde, at Rudolf II, som selv var tysker og katolik, viste stor forståelse over for andre nationaliteter og andre verdensopfattelser, men inden for Borgbyens rammer var problemet til at overse. Derimod lå der politisk sprængstof i placeringen af det habsburgske magtcentrum i en by og i et land med en ret homogen tjekkisk befolkning, der siden Johannes Hus' dage († 1415) var protestanter. Mest spændt var forholdet i Prag. Nede i Den gamle og Den ny By var indbyggerne tjekkere og protestanter, ligesom kirker og skoler her var protestantiske.

Indførelsen af reformationen i Tyskland blev til stor støtte for tjekkisk protestantisme. Præsteuddannelsen foregik nu ved de tyske universiteter, og det blev også almindeligt at betragte videregående studier ved et tysk universitet som en forudsætning for at blive ansat ved Karlsuniversitetet, der så selv tog sig af uddannelsen af lærerkræfter til latinskolerne. Allerede i 1556 havde jesuitterne dog som modvægt oprettet et katolsk universitet i Clementinum i Prag (der nu huser Nationalbiblioteket), og i 1569 grundlagde de også et universiteti Olomouc i Mæhren.

I 1609 blev der vedtaget love, der skulle sikre fri religionsudøvelse og styrke Karlsuniversitetets position. Det faldt svært at føre lovene ud i livet, men netop i 1609, da det hele tegnede så lyst, dukkede en dansker, Bertel Knudsen (15881650), op i Prag. Han kaldte sig også Toxotes efter sin mor, der var født Schytte, og senere også Aquilonius efter faderen, en Nordrup. Knudsen var blevet baccalaur og var taget ud på en rejse, som kom til at vare i fire år og førte ham vidt omkring i Europa, ja endda helt til Lilleasien. Han indskrev sig ved Karlsuniversitetet som Bartholomæus Canutius Danus, fik stipendium og studerede et helt år i Prag. Det kan nok overraske, at han valgte Prag. Vel kom der i disse år en del skandinaver til Prag (bl.a. Tyge Brahes svoger Erik Lange), men de søgte deres lykke i Borgbyens internationale miljø. Karlsuniversitetet, der på det tidspunkt var meget nationalt præget, blev praktisk taget kun søgt af tjekkere. Det kan lyde som et paradoks, men det katolske universitet $\mathrm{i}$ Olomouc var langt mere attraktivt for udlændinge, - i årene 1590-1625 var endda op imod en snes danskere immatrikuleret der. Se Fr. Cinkes udgave af matriklen i Rocenka Cyrilometodejské fakulty bohoslovecké v Olomouci 1918-1928, Olomouc 1929, s. 42-157.

Karlsuniversitetet var ret godt med inden for de eksakte videnskaber uden dog at nå op på det niveau, der blev angivet af de kejserlige matematikere og 


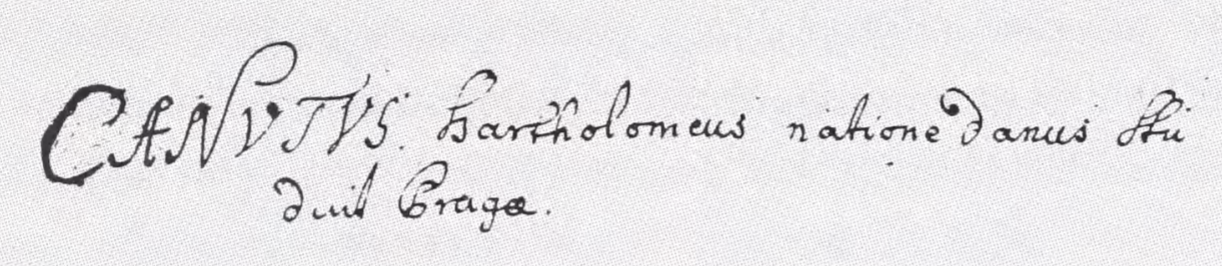

$$
\begin{aligned}
& \text { veripta is De Ltteranem Sroffantia Carmen-cui sti } \\
& \text { colaus Troulus Programma prannit- Prage } \\
& \text { ifio. rafiof } \\
& \text { 2) Pufrum fuvenilum âlien I ctII. Prago } \\
& \text { Jypis Paudi eñü toro } 8 \\
& \text { (3) Lufuum fuveniluemi Liber II. Praga bitori } \\
& \text { ayud andom } 1970
\end{aligned}
$$

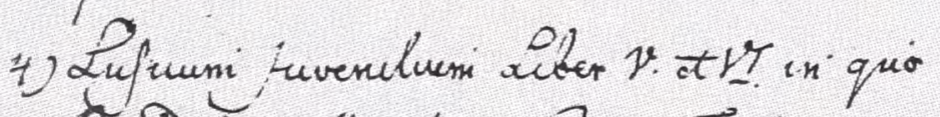

$$
\begin{aligned}
& \text { Parrobe Horatw Prage Tapis geonga. } \\
& \text { Hanufiu Eduigcorgio Hanuforo an fflute. }
\end{aligned}
$$

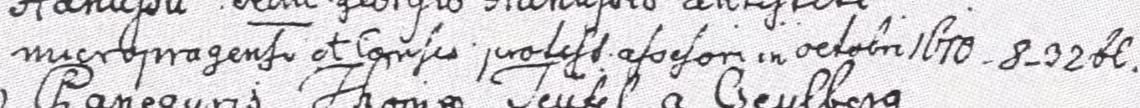

$$
\begin{aligned}
& \text { 5) Fanegyri Therme veufel a leyblorg. } \\
& \text { un augmentum fonoris dicia- Srago }
\end{aligned}
$$

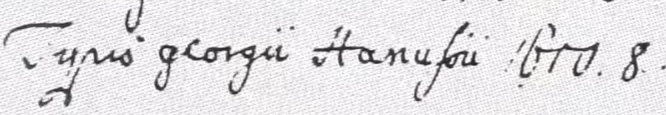

I en bibliografi over den humanistiske latindigtning i Bøhmen og Mæhren findes denne registrering af fem skrifter fra Knudsens hånd, udgivet i Prag i 1610. Der kan dog stilles spørgsmål ved korrektheden af oplysningerne. (Det mæhriske landsarkiv i Brno, sign.: J.P. Cerroni, G 12 - I/101, fol 57a).

astronomer. Inden for humaniora stod universitetet svagt. Nu kan man næppe mistænke den unge Knudsen for at have haft videnskabelige ambitioner. Det mest sandsynlige er, at han har følt sig tiltrukket af Karlsuniversitetet som digterskole. Universitetet havde længe været midtpunkt for den humanistiske latindigtning i Bøhmen og Mæhren. Der blev digtet på livet løs. Her kunne Knudsen rigtig boltre sig i kappestrid med de øvrige akademiske borgere.

Man digtede om alt muligt mellem himmel og jord, og de mange bogtrykkerier, der dukkede op i Prag og andre byer, fik nok at bestille. Denne latindigtning greb sådan om sig, at en bibliografi over den humanistiske latindigtning i Bøhmen og Mæhren fylder hele fem tykke bind, og så er et annonceret supplementsbind endda ikke udkommet.

Man tror det næppe, men i denne bibliografi optræder Knudsen med ikke 
mindre end fem skrifter, der alle skulle være udgivet i Prag i 1610, se: Antonín Truhlár, Rukovet' humanistického básnictví I, Praha 1966, s. 300-301. Her bliver vi ganske vist nødt til at sætte et stort spørgsmålstegn ved Lusuum juvenilium liber I-II, der ifølge Bibliotheca Danica ikke er udkommet i Prag, og et stort spørgsmålstegn også ved liber III, der nok er omtalt i mæhrisk arkivmateriale, men ikke findes i tjekkiske biblioteker. De andre skrifter, der anføres i bibliografien, findes alle på Nationalbiblioteket i Prag, nogle endda i to eksemplarer. Det drejer sig om Lusuum juvenilium liber IV og liber V-VI, men ud over disse "Ungdommelige Lege" også om et skrift på over 400 heksametre til ære for en Thomas Teufel. Desuden er der i bibliografien gjort rede for fire bidrag af Knudsen til antologier, som også er udgivet i Prag i 1610. Disse skrifter har Det kongelige Bibliotek ikke hidtil haft kendskab til. De er kommet for dagens lys under den kortlægning af dansk litteraturs udbredelse, som biblioteket er i gang med i Den tjekkiske Republik.

Skrifterne omfatter op imod 200 digte, de fleste helt små, men undertiden i ret indviklede versemål. De fleste digte er hilsener til venner og bekendte i Danmark, men ca. 40 digte berører tjekkiske forhold og vidner om, at Knudsen faldt godt til i det fremmede miljø. Nogle af disse digte er viet alma mater og studenterungdommen i Prag i almindelighed, men de allerfleste er rettet til navngivne personer. Ud fra devisen: sig mig, hvem du omgås, så skal jeg sige dig hvem du er, vil jeg her i korthed gøre rede for, hvem den unge Knudsen har betænkt med digte. Det er lykkedes at identificere næsten alle adressater.

En del digte er skrevet til universitetets professorer, således et til rektor, astronomen Martin Bachácek, og et til profesor Friedrich Taubmann fra Wittenberg. Begge var bekendte af Tyge Brahe. Godt en halv snes digte er rettet til studiekammerater i anledning af offentlige deklamationer, afsluttende eksamener, forlovelser, giftermål m.m. Seks digte er til en Václav Rokycansky, der selv digtede og i 1609 netop havde fået udgivet sin første digtsamling.

Der var dengang kun en 40-50 studerende ved Karlsuniversitetet. De boede samlet på kollegier, de fleste på Carolinum (indgang fra Frugttorvet eller Celetná), hvor også professorerne boede og forelæste. Det var en sluttet kreds, hvor alle kom hinanden ved.

Knudsen selv boede på Allehelgenskollegiet, der lå ved Storetorv bag rådhuset (matr. nr. 16, i dag kommunekontor). To af Knudsens digte er tilegnet eforen, professor Johannes Campanus, der gjaldt for tidens førende tjekkiske latindigter, - og som i øvrigt også havde skrevet et digt til minde om Tyge Brahe (i sit hefte Anni supra sesquimillesimum C. primi brevis descriptio, Prag 1602). 
På dette kollegium optog man dengang også udenbys latinskoleelever. Karlsuniversitetet og latinskolerne var forbundne kar. Universitetet koncentrerede sig helt om at uddanne lærere til latinskolerne, som de endda havde overopsyn med. Det var almindeligt, at studerende, der havde opnået baccalaurgraden, tjente en ekstra skilling ved at have timer på latinskolerne i Prag. Det gjaldt også Knudsen. Så vidt vi kan skønne af adressaterne til hans digte, underviste han ved to skoler. Han har skrevet digte til rektorerne for skolerne ved Skt. Ægidius' Kirke og ved Skt. Mikaels Kirke, og i hvert fald også ét til en elev.

De to kirker ligger i Storetorvs umiddelbare nærhed, men ingen af dem nåede helt ud til torvet. Tejn-kirken, der som beskrevet af H.C. Andersen har indgang "over gården", er ikke noget enestående tilfælde. Skt. Mikaels Kirke har også en ejendom foran sig, så man skal igennem en smøge og ind i en gård for at komme til indgangen. H.C. Andersens karakteristik af Tejn-kirken - "lille, fattig" - passer faktisk meget bedre på Skt. Mikaels Kirke. Alligevel skal man vogte sig for at kalde en kirke lille og ubetydelig. Nationalbiblioteket, der for nogle år siden havde fået bygningen overdraget til depot, fik efter fløjlsrevolutionen i 1989 et nyt og bedre depot, og for at skaffe penge til istandsættelse af det, blev Skt. Mikaels Kirke i efteråret 1993 solgt på en auktion for 130 mio. tjekkiske kroner. Den nuværende barokbyning (servitterkirke) har ikke engang et tårn. Men salget havde affødt en storm af protester i aviser og fjernsyn, og handelen måtte gå tilbage. Kirken havde ganske vist tjent som lagerbygning helt siden 1786, da den blev lukket som følge af Josef II's forordning om lukning af klostre og klosterkirker, men at sælge en kirke til kommerciel udnyttelse for højeste bud blev alligevel for meget for Karlsuniversitetets studenter, der førte an i protesterne. Forøvrigt var Skt. Mikaels Kirke slet ikke nogen ubetydelig kirke: Hus selv og fremtrædende husitter havde prædiket her. I 1610 hed præsten Esaias Camillus. Ham har Knudsen også skrevet et digt til. Denne præst var måske ikke nogen særlig produktiv skribent, men han ser ud til at have været midtpunkt i en klike, og hans venner blev også Knudsens venner.

Tæt bag ved Skt. Mikaels Kirke ligger Teufelgården. Her boede den stenrige Thomas Teufel, som Knudsen havde viet et helt skrift til. Han har sikkert optrådt som sponsor for aktiviteter i kvarteret. Trods navnet var han en god protestant. Han blev adlet i 1619 af den protestantiske kong Friedrich af Pfalz.

Et par lidt længere digte er tilegnet Johannes Kepler. Det bør nævnes, at Kepler i langt højere grad end Brahe levede med i Karlsuniversitetets liv. I 1609, da cølibat for universitetsprofessorer blev ophævet, prøvede man at oprette et 
professorat til ham. Det kom der nu ikke noget ud af. Men en stor del af de tolv år, han tilbragte i Prag, boede han, selv om han efter Brahe blev kejserlig matematiker og astronom, nede i Den gamle By, 1605-1607 hos universitetets rektor Martin Bachácek (Frugttorvet, matr. nr. 587/I) og derefter indtil 1612 i Jesuittergaden (nu Karlsgade, matr. nr.188/I, over for Clementinum lige før Karlsbroen).

Et andet bekendtskab var Georg Hanus, der var ejer af et trykkeri og forlægger for to af Knudsens skrifter. Han var præst ved Skt. Nikolaj Kirke ovre på Lillesiden. Ham har Knudsen været rigtig gode venner med og skrevet en halv snes digte til.

Der er vel ingen i det 20. århundrede, der sætter lejlighedsdigtning særlig højt. Knudsens digte er måske enkelte steder lidt vel panegyriske, men er ellers blufærdige, som det sømmer sig for sympatitilkendegivelser mænd imellem. Der er ingen tvivl om, at det har moret ham at skrive vers til venner og bekendte. Det var ung leg.

Knudsen kom af gode grunde kun sammen med folk, der kunne latin. Men hans omgangskreds bestod så godt som udelukkende af tjekkere og protestanter. Man skal selvfølgelig ikke tro, at nationalitet og religion var de eneste og altafgørende spørgsmål. I det daglige var det handelen, der kom i første række. De institutioner, vi har omtalt, universiteter, kollegier, skoler og kirker, ligger alle ved en "torvevej": fra Hestetorvet går man mellem Frugttorvet og Haveltorvet (der i dag har overtaget rollen som frugt- og grønttorv) videre over Storetorv og Lilletorv og så over Karlsbroen til Lillesidetorvet. Det var dengang byens hovedfærdselsåre. Denne vej bliver i turistbrochurer kaldt for "kongevejen", fordi de habsburgske kejsere, når de tog fra Wien til Prag for at blive kronet og hyldet som bøhmiske konger, kom den vej. Kejserens kortege kom ind ad den byport, der hedder Krudttårnet, og kørte så ellers ad samme rute over Karlsbroen helt op til slottet: Men navnet "kongevej" ville i vort tilfælde være lidt for prætentiøst. Vi kan standse op ved Lillesidetorvet, for Knudsen havde ikke ærinder længere oppe. Han var tro over for sin tjekkiske, protestantiske omgangskreds. Det skulle have været nemt for ham netop som digter at indynde sig hos mennesker, der kunne introducere ham ved hoffet og hos kejseren, og eventuelt opnå titel af poeta caesareanus. Den svenske historiker Johannes Messenius opnåede titelen i 1605 i omtrent samme unge alder. Knudsen synes ikke at have haft nogen aspirationer i den retning.

Bertel Knudsen tog hjem i april 1610 uden denne titel, men ladet med mange nye indtryk og med lyst til at fortsætte sin digterkarriere. Han blev noget af 
en ener i dansk litteratur. Humanistisk poesi havde ikke i samme grad vundet indpas i Danmark, og interessen for den var på Knudsens tid nærmest vigende. Man kan godt kalde hans lyre for enstrenget. Han holdt sig til én bestemt genre, sympatitilkendegivelsen, som han så til gengæld var meget produktiv i. Men det, der måske ud fra litteraturhistorisk vurdering synes at være en mangel, kan vise sig at være en fordel for personalhistorikeren: Knudsens digtning er en enestående kilde for den, der ikke blot vil tegne et portræt af forfatteren, men også vil give en skildring af det miljø, han bevægede sig i.

I 1618, ikke mange år efter, at Knudsen var vendt hjem, rejste de bøhmiske stænder sig til modstand mod kejservældet. De led det endelige nederlag i 1620 i det berømte slag på Det hvide Bjerg, et højtliggende plateau, der dengang lå et par kilometer uden for bygrænsen, men nu er indlemmet i Prag. Brahes gode ven Johannes Jessenius, der dengang var rektor for Karlsuniversitetet, delte i 1621 skæbne med 26 andre oprørere og blev henrettet på Storetorv. Derefter tog rekatoliseringen fart. Nogle reddede sig ved i hvert fald officielt at skifte tro, andre emigrerede. Johannes Hus' lære levede fra nu af kun videre i udlandet (Johannes Amos Comenius, De bøhmiske eller mæhriske Brødre, Herrnhuterne). Mange emigranter fandt - allerede dengang - vej til Danmark. 